\title{
Iwayoside A, a New Diterpene Glycoside from Artemisia iwayomogi Kitamura that Enhances IL-2 Secretion
}

\author{
Yan Ding, Chun Liang, Seo Young Yang, Jun Ho Kim, ${ }^{\dagger}$ Young Mi Lee, ${ }^{\dagger}$ and Young Ho Kim* \\ College of Pharmacy, Chungnam National University, Daejeon 305-764, Korea.*E-mail: yhk@cnu.ac.kr \\ ${ }^{\dagger}$ College of Pharmacy, Wonkwang University, Iksan, Jeonbuk 570-749, Korea \\ Received May 17, 2010, Accepted June 30, 2010
}

Key Words: Artemisia iwayomogi Kitamura, Iwayoside A, IL-2

Interleukin 2 (IL-2) is a member of the cytokine family that is normally produced by the body during an immune response. ${ }^{1}$ Antigen binding to the T cell receptor stimulates the secretion of IL-2, which is necessary for the development of T cell immunologic memory, one of the unique characteristics of the immune system. IL-2 facilitates the production of immunoglobulins made by $\mathrm{B}$ cells and induces the differentiation and proliferation of natural killer cells. ${ }^{2}$ It has been approved by the Food and Drug Administration (FDA) for the treatment of malignant melanoma and renal cell cancer and is in clinical trials for the treatment of chronic viral infections and as a adjuvant for vaccines.

Artemisia iwayomogi Kitamura, a member of the Compositae, is a perennial herb that is common in Korea. It has drawn considerable interest because the plant is believed to have chemopreventive potential. ${ }^{3-4}$ A previous chemical investigation of this plant studied the effects of phenolic compounds on the function of osteoblastic MC3T3-E1 cells. ${ }^{5}$ In another study, AIP1, a water-soluble carbohydrate fraction from A. iwayomogi, showed anti-tumor and immunomodulating activities. ${ }^{6}$ In addition, the aqueous extract of $A$. iwayomogi prevented the immediate-type allergic reaction and inflammatory cytokine secretion in mast cells.

As a part of our ongoing search for bioactive compounds from natural products, one new diterpene glycoside (1), named iwayoside A, together with two monoterpenes, unshuoside A (2) and $\alpha$-terpinyl- $O-\beta$-D-glucoside (3), were isolated from the aerial parts of $A$. iwayomogi. The chemical structures of these compounds were confirmed, as shown in Fig. 1, by interpretation of measured 1D and 2D NMR spectroscopic data and by comparison of those data with published values. Both compounds $\mathbf{2}$ and $\mathbf{3}$ were isolated for the first time from Artemisia species. This paper also reports their enhanced IL-2 secretion caused by these compounds.

Compound 1 was obtained as a white powder and its elemental composition was determined to be $\mathrm{C}_{26} \mathrm{H}_{44} \mathrm{O}_{8}$ by HR-ESI-MS. The ${ }^{1} \mathrm{H}$-NMR spectrum revealed the presence of one $\beta$-glucopyranose unit from the anomeric proton signal at $\delta 4.27(1 \mathrm{H}$, $\mathrm{d}, J=8.0 \mathrm{~Hz}$ ), and the signals of three methyl groups at $\delta 0.75$ (s), 0.95 (s), and 1.05 (s) of the aglycone moiety. The ${ }^{13} \mathrm{C}-\mathrm{NMR}$ spectrum of compound $\mathbf{1}$ indicated the presence of one sugar unit along with 20 carbon signals for the aglycone moiety, which indicated that it has a diterpene skeleton. These signals were assigned to three methyl signals, seven methylene signals, seven methine signals, and three quaternary carbons from HMQC spectra. These signals are similar to those of ent-kau- rane-3 $\alpha, 16 \beta, 17$-triol 17-O- $\beta$-D-glucoside, ${ }^{8}$ which was isolated from Rubus suavissimus, except for the stereochemistry of position-3. Low-field moving of C-3 $(\delta 79.7)$ and a proton signal at $\delta 3.11(\mathrm{dd}, J=4.6,11.6 \mathrm{~Hz})$ indicated that the hydroxyl group in position- 3 should be the $\beta$-form, which is supported by those of ent-kaurane-3 $\beta, 16 \beta, 17$-triol. ${ }^{9}$ The peak of the acid hydrolysate of 1 was detected at $t_{\mathrm{R}}(\mathrm{min}) 14.21$ by GC analysis and identified as D-glucose after comparison with the retention times of the authentic samples after treatment with trimethylsilylimidazole in pyridine. Analysis of two-dimensional NMR data for compound 1 revealed that its structure was ent-kaurane$3 \beta, 16 \beta, 17$-triol 17-O- $\beta$-D-glucoside, named iwayoside A.

When splenocytes were cultured with each of the isolated compounds at concentrations of $5-100 \mu \mathrm{M}$, compounds 1-3 enhanced the IL-2 secretion, as shown in Table 2. In particular,

Table 1. NMR spectral data of compound 1

\begin{tabular}{|c|c|c|c|}
\hline & $\delta_{\mathrm{C}}$ (mult.) & $\delta_{\mathrm{H}}(J$ in $\mathrm{Hz})$ & HMBC \\
\hline 1 & $39.9(\mathrm{t})$ & $0.89 \mathrm{dt}(3.6,13.2), 1.82 \mathrm{~d}(13.2)$ & $\mathrm{C}-2,3,5,9,10,20$ \\
\hline 2 & $27.9(\mathrm{t})$ & $1.67 \mathrm{~m}, 1.58 \mathrm{~m}$ & C-10, \\
\hline 3 & $79.7(d)$ & $3.11 \mathrm{dd}(4.6,11.6)$ & $\mathrm{C}-1,18,19$ \\
\hline 4 & $39.9(\mathrm{~s})$ & & \\
\hline 5 & $56.5(\mathrm{~d})$ & $1.76 \mathrm{~m}$ & C- $6,7,9,18,20$ \\
\hline 6 & $21.3(\mathrm{t})$ & $1.60 \mathrm{~m}, 1.40 \mathrm{~m}$ & \\
\hline 7 & $43.2(t)$ & $1.64 \mathrm{~m}, 1.49 \mathrm{~m}$ & C-6 \\
\hline 8 & $45.5(\mathrm{~s})$ & & \\
\hline 9 & $58.1(\mathrm{~d})$ & $0.98 \mathrm{~m}$ & C- $8,10,14,15$ \\
\hline 10 & $40.2(d)$ & & \\
\hline 11 & $19.5(\mathrm{t})$ & $1.60 \mathrm{~m}$ & \\
\hline 12 & $27.2(\mathrm{t})$ & $1.50 \mathrm{~m}, 1.73 \mathrm{~m}$ & \\
\hline 13 & $46.8(d)$ & $2.06 \mathrm{~m}$ & $\mathrm{C}-8,11,14,16$ \\
\hline 14 & $38.1(\mathrm{t})$ & $1.92 \mathrm{~d}(11.6), 1.59 \mathrm{~m}$ & $\mathrm{C}-8,9,12,13,15,16$ \\
\hline 15 & $53.5(\mathrm{t})$ & $1.50 \mathrm{~d}(14.0), 1.39 \mathrm{~d}(14.0)$ & $\mathrm{C}-7,8,9,14,16,17$ \\
\hline 16 & $82.1(\mathrm{~s})$ & & \\
\hline 17 & $75.2(\mathrm{t})$ & $4.20 \mathrm{~d}(10.2), 3.49 \mathrm{~d}(10.2)$ & C-1', $13,15,16$ \\
\hline 18 & $16.2(q)$ & $0.75 \mathrm{~s}$ & $\mathrm{C}-3,5,4,19$ \\
\hline 19 & $28.9(q)$ & $0.95 \mathrm{~s}$ & C- $-3,5,4,18$ \\
\hline 20 & $18.4(q)$ & $1.05 \mathrm{~s}$ & C- $5,9,10$ \\
\hline $1^{\prime}$ & $105.3(\mathrm{~d})$ & $4.27 \mathrm{~d}(8.0)$ & \\
\hline $2^{\prime}$ & $75.3(d)$ & $3.21 \mathrm{dd}(8.0,8.8)$ & $\mathrm{C}-1^{\prime}, 3^{\prime}, 4^{\prime}$ \\
\hline $3^{\prime}$ & 77.9 (d) & $3.26 \mathrm{t}(8.8)$ & $\mathrm{C}-2^{\prime}$ \\
\hline $4^{\prime}$ & 71.7 (d) & $3.27 \mathrm{~m}$ & \\
\hline $5^{\prime}$ & 78.1 (d) & $3.26 \mathrm{~m}$ & \\
\hline $6^{\prime}$ & $62.8(\mathrm{t})$ & $\begin{array}{l}3.86 \mathrm{dd}(2.0,12.0) \\
3.66 \mathrm{dd}(5.0,12.0)\end{array}$ & $\mathrm{C}-4^{\prime}, 5^{\prime}$ \\
\hline
\end{tabular}




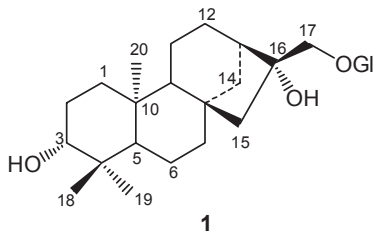

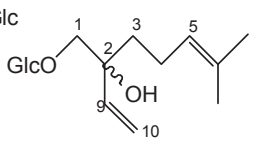

2

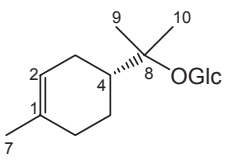

3
Figure 1. Structures of compounds 1-3.

Table 2. Effect of compounds 1-3 on IL-2 release

\begin{tabular}{cccc}
\hline \multirow{2}{*}{ Comp. } & \multicolumn{3}{c}{ IL-2 release $(\mathrm{pg} / \mathrm{ml})$} \\
\cline { 2 - 4 } & $5 \mu \mathrm{M}$ & $25 \mu \mathrm{M}$ & $100 \mu \mathrm{M}$ \\
\hline Negative control & & 13.70 \\
\hline control (+con A) & 387.19 & \\
\hline $\mathbf{1}$ & 40.37 & 43.58 & 43.95 \\
$\mathbf{2}$ & 27.12 & 26.08 & 49.45 \\
$\mathbf{3}$ & 24.80 & 32.11 & 32.70 \\
\hline
\end{tabular}

compounds 1 and 2 resulted in respective 3.2- and 3.6-fold increases in IL-2 secretion, as compared to the negative control at a concentration of $100 \mu \mathrm{M}$. In addition, IL-2 secretion was increased 2.4-fold in the presence of compound 3 at a concentration of $100 \mu \mathrm{M}$.

\section{Experimental Section}

General methods. Optical rotations were measured on a JASCO DIP-360 digital polarimeter. NMR spectra were recorded on a Bruker DRX 400 and 500 NMR spectrometers using TMS as an internal standard. HR-ESI-MS was carried out on a JMS-T100TD spectrometer (Tokyo, Japan). GC spectra were recorded on a Shidmazu-2010 spectrometer. Column chromatography was conducted using silica gel 60 (40 - 63 and 63 - 200 $\mu \mathrm{m}$ particle size) and RP-18 (40 - $63 \mu \mathrm{m}$ particle size), which were both obtained from Merck.

Plant material. Aerial parts of A. iwayomogi (Compositae) were collected at Jeju island in June 2007 and taxonomically identified by one of us (Young Ho Kim). A voucher specimen (CNU07105) has been deposited at the herbarium of the College of Pharmacy, Chungnam National University, Korea.

Extraction and isolation. The plants $(3 \mathrm{~kg})$ were extracted with $70 \% \mathrm{MeOH}$ at room temperature for 1 day $(3 \times 10 \mathrm{~L})$. The $70 \% \mathrm{MeOH}$ extract ( $294 \mathrm{~g}$ ) was concentrated under vacuum to give a gummy residue, which was then suspended in $\mathrm{H}_{2} \mathrm{O}(3 \mathrm{~L})$. This solution was extracted with EtOAc $(3 \times 3 \mathrm{~L})$ to give $45 \mathrm{~g}$ of a EtOAc soluble fraction and $220 \mathrm{~g}$ of a $\mathrm{H}_{2} \mathrm{O}$ soluble fraction. The $\mathrm{H}_{2} \mathrm{O}$ soluble fraction ( $215 \mathrm{~g}$ ) was subjected to highly porous synthetic resin column chromatography using a stepwise gradient of $\mathrm{H}_{2} \mathrm{O}-\mathrm{MeOH}(1: 0 \rightarrow 3: 1 \rightarrow 1: 1 \rightarrow 1: 3 \rightarrow 0: 1)$, to yield five fractions (Fr. 1-5). Fraction Fr.4 was chromatographed on a silica gel column eluted with $\mathrm{CHCl}_{3}-\mathrm{MeOH}-\mathrm{H}_{2} \mathrm{O}$ stepwise gradient $(16: 1: 0.1 \rightarrow 8: 1: 0.1 \rightarrow 4: 1: 0.1)$, to yield 9 subfractions (Fr. 4A-4I). Compounds 2 (5 mg) and 3 (16 mg) were obtained from Fraction 4I using a reversed-phase (RP) $\mathrm{C}_{18}$ column eluted with Acetone- $\mathrm{H}_{2} \mathrm{O}(1: 2)$. Fraction 5 was chromatographed on a silica gel column eluted with $\mathrm{CHCl}_{3}-\mathrm{MeOH}-\mathrm{H}_{2} \mathrm{O}$ stepwise gradient $(10: 1: 0.1 \rightarrow 5: 1: 0.1 \rightarrow 3: 1: 0.1)$, to yield four subfractions (Fr. 5A-5E). Compound 1 (50 mg) was obtained from Frac- tion 5D using a $\mathrm{RP} \mathrm{C}_{18}$ column eluted with $\mathrm{MeOH}-\mathrm{H}_{2} \mathrm{O}(1: 3)$.

Iwayoside A (1): White powder; $[\alpha]_{\mathrm{D}}^{20}-35.3(c 0.2, \mathrm{MeOH})$; ${ }^{1} \mathrm{H}-\mathrm{NMR}\left(\mathrm{CD}_{3} \mathrm{OD}, 500 \mathrm{MHz}\right)$ and ${ }^{13} \mathrm{C}-\mathrm{NMR}\left(\mathrm{CD}_{3} \mathrm{OD}, 125\right.$ $\mathrm{MHz}$ ) see Table 1; ESI-MS $m / z 485[\mathrm{M}+\mathrm{H}]^{+}$; HR-ESI-MS $m / z 483.2966$ [M - H] , (cacld. for $\mathrm{C}_{26} \mathrm{H}_{43} \mathrm{O}_{8}, 483.2958$ ).

Spleen cell preparation. Spleens from sacrificed BALB/c mice were immediately homogenized between frosted glass slides and washed in complete medium (RPMI $1640+10 \%$ FBS). The splenocyte suspension was overlaid on Histopaque (Sigma, St Louis, MO), and centrifuged at $1000 \mathrm{~g}$ to remove erythrocytes and dead cells. Cells recovered from the interface were washed in complete medium and counted using a hemocytometer. The viability of the splenocytes was confirmed by Trypan blue exclusion.

IL-2 analysis. For stimulation cultures, prepared splenocytes were placed in the wells of a 24-well culture plate at $1 \times 10^{6}$ cells $/ \mathrm{mL}$ with either $500 \mathrm{ng} / \mathrm{mL}$ concanavalin A (Con A, Sigma) or one of the compounds added to the cultures. The supernatants from the Con A or compound-stimulated cultures were collected at $24 \mathrm{~h}$ for IL-2 determination, and stored at $-80{ }^{\circ} \mathrm{C}$ until further analysis of the IL-2 levels using a standard cytokine sandwich enzyme-linked immunosorbent assay (ELISA). Purified recombinant IL-2 (BD Biosciences, CA) was used as a standard for calculating the IL-2 concentrations in the supernatants. ELISA for IL-2 was carried out in 96-well ELISA plates (Nunc, Denmark) coated with $100 \mu \mathrm{L} /$ well of capture antibody in coating buffer (1:250 dilution) and incubated overnight at $4{ }^{\circ} \mathrm{C}$. The plates were washed and blocked with $200 \mu \mathrm{L} /$ well assay diluent and incubated at room temperature for $1 \mathrm{~h}$. After washing, the sample or IL-2 standard was added and incubated at room temperature for $2 \mathrm{~h}$. After a 2 -h incubation at room temperature, the wells were washed and then $100 \mu \mathrm{L}$ of prepared working detector was added to each well and incubated for $1 \mathrm{~h}$ at room temperature. The wells were washed again and TMB substrate was added. Color development was measured at $405 \mathrm{~nm}$ using an automated microplate ELISA reader.

Acknowledgments. This work was supported by Priority Research Centers Program through the National Research Foundation of Korea (NRF) funded by the Ministry of Education, Science and Technology (2009-0093815). We are deeply grateful to the Korean Basic Science Institute (KBSI) for performing the NMR analysis.

\section{References}

1. Cantrell, D. A.; Smith, K. A. Science 1984, 224, 1312.

2. Waldmann, T. A. Nature Rev. Immun. 2006, 6, 595.

3. Lee, S. B.; Cho, T. S.; Yoon, K. W.; Lee, J. C.; Shim, S. B. J. Appl. Pharmacol. 1998, 6, 119.

4. Lee, K. R.; Zee, O. P.; Kwak, J. H.; Kim, Y. S.; Park, H. K.; Koo, K. A.; Youn, H. J. Kor. J. Pharmacogn. 1993, 24, 289.

5. Ding, Y.; Liang, C.; Choi, E. M.; Ra, J. C.; Kim, Y. H. Nat. Prod. Sci. 2009, 15, 192

6. Koo, K. A.; Kwak, J. W.; Lee, K. R.; Zee, O. P.; Woo, E. R.; Park, H. K.; Youn, H. J. Arch. Pharm. Res. 1994, 17, 371.

7. Shin, T. Y.; Park, J. S.; Kim, S. H. Immunopharm. Immunot. 2006, $28,421$.

8. Hirono, S.; Chou, W. H.; Kasai, R.; Tanaka, O.; Tada, T. Chem. Pharm. Bull. 1990, 38, 1743.

9. Li, X.; Zhang, D. Z.; Onda, M.; Konda, Y.; Iguchi, M.; Harigaya, Y. J. Nat. Prod. 1990, 53, 657. 